\title{
THE COST OF NOT BREASTFEEDING IN NORTH SUMATERA
}

\author{
Estro Dariatno Sihaloho \\ Department Economics of Padjadjaran University \\ Email: estro.sihaloho@unpad.ac.id \\ Rahma \\ Master Economics of Lund University \\ Email: rahmaherman@gmail.com \\ Wandira Larasati Senja \\ The SMERU Research Institute \\ Email: wandirasenjalarasati@gmail.com \\ Pipit Pitriyan \\ Email: pipit.pitriyan@unpad.ac.id \\ Adiatma Y.M Siregar \\ Department Economics of Padjadjaran University \\ Email: adiatma.siregar@unpad.ac.id
}

\begin{abstract}
Breastfeeding provide many good impacts on health and economics side. This study tries to estimate the economic impact of not breastfeeding due to diarrhea and PRD cases in North Sumatera. The economic impact elaborated by finds health system medical cost and the patient/non-medical cost. This paper calculates health system medical cost from public hospital, private hospital, and primary health center while the patient cost calculated from 135 patients in 3 kinds of health facilities. This paper combines primary data with Census Data 2010 and IDHS 2012 to get total cost of not breastfeeding in North Sumatera. The costing process shows there are economic loss about US $\$ 1,290,582$ with average cost about US\$ 13.48 in North Sumatera. The total cost consist of health system perspective cost about US\$ 799,050 and patient costs about 491,532. This show that most of the cost comes from the health system cost/medical cost about $61.91 \%$ and the $38.09 \%$ borne from the patient costs and non-medical cost
\end{abstract}

Key words:Cost of Not Breastfeeding, Costing Analysis, North Sumatera

\section{INTRODUCTION}

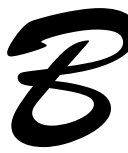

reastfeeding has many health benefits to infant and their mothers both in short term and long term (Binns, Lee, \& Low, 2016). Reducing the risk of morbidity and mortality due to diarrhea and QE Journal | Vol.07 - No.03December 2018 - 191 
pneumonia/respiratory disease (PRD) are example of health benefits of breastfeeding (Siregar, Pitriyan, \& Walters, 2018). Many factors influence breastfeeding practice including public health facilities effect on breastfeeding initiation practices (Karim et al., 2018). The lack of breastfeeding promoting in hospitals contributes to high levels of not breastfeeding (United Nations Children's Fund, 2012).

In 2015, there are 63 public hospitals, 151 private hospitals, 571 primary health centers, 1.846 health posts, and 4716 public clinics in North Sumatera (Statistics of North Sumatera, 2016). There is no significance increasing number of health facilities in North Sumatera. In 2014, there are 60 public hospitals, 146 private hospitals, 570 primary health centers, 1.972 health posts, and 7.684 public clinics in North Sumatera. Even there was decreasing of public clinics from 7.684 in 2014 become 4716 in 2015 (Statistics of North Sumatera, 2016). This is a relatively small number of health facilities given that more than 280.000 children are born every year in North Sumatera Province (Statistics of North Sumatera, 2016). The constraints on the health system also constrain the ability to promote breastfeeding and other healthy behaviors.

Beside health benefit, breastfeeding also has economic impact for parents, insurance companies, employers, and society in general (Bartick et al., 2013). In seven countries in South East Asia, the annual treatment cost stemming from cases of childhood diseases attributed to not breastfeeding is about US\$293.55million (Walters et al., 2016). In Indonesia, the cost of not breastfeeding from the healthcare system was estimated about US\$118 million annually (Siregar et al., 2018). In this research, we aim to present the economic impact of not breastfeeding due to treatment costs of diarrhea and PRD from healthcare provider perspective and patient perspective in North Sumatera Province.

Cost of illness (COI)

Cost-of-illness (COI) was the first economic evaluation technique used in the health field (Tarricone, 2006). Cost of illness (COI), known as burden of disease (BOD), is a definition that encircle various aspects of the disease impact on the various outcomes in a country, specific regions, communities, and even individuals (Jo, 2014). The purpose of a cost of illness calculation is to identify and measure all the costs of a particular 
disease, including the direct, indirect, and intangible dimensions (Byford, Torgerson, \& Raftery, 2000). Calculation results of COI are typically divided into two major categories: (1) core costs are those resulting directly from the illness and (2) other related costs include non-health costs of the illness (Rice, 2000). Analyzing cost of illness will provide useful opportunities for communicating with the public and policymakers on the relative importance of specific diseases (Clabaugh \& Ward, 2008). Accurate calculation and knowledge about COI is important and helps us formulate health care policies and interventions and eventually allocate health care resources in accordance with budget constraints in order to achieve policy efficiency (Jo, 2014).

\section{Cost of Not Breastfeeding}

Previous study have found that breastfeeding are the best nutrition for infant (Riordan, 1997), particularly only give exclusive breastfeeding in first 6 months and still continue providing breastfeeding at least until child's first year of life while giving the introduction of solid food (Victora et al., 2016). Not breastfeeding can increase the risk of negative health outcome to infants and children (Bartick et al., 2013), Several studies has already found the evidence that breastfeeding has also lifelong effect in adulthood (RichEdwards et al., 2004; Victora et al., 2016).

Lamberti et all (2011) confirmed breastfeeding can prevent the diarrhea morbidity and mortality (Lamberti, Fischer Walker, Noiman, Victora, \& Black, 2011). The finding report that exclusive breastfeeding for the first 6 months is become child survival intervention and continued breastfeeding throughout the first two years can protect against diarrhea-specific morbidity and mortality. Lamberti et all (2011) also highlighted that breastfeeding can prevent pneumonia - specific and the important role of exclusive breastfeeding during the first six months.

Adiatma et all (2018) calculates that Not Breastfeeding give big loss to economic of Indonesia. The healthcare system cost due to not breastfeeding was estimated about US\$118 million annually that consist of US\$88.64 million of provider costs and US $\$ 29.98$ million of non-medical patient costs (Siregar et al., 2018). 


\section{RESEARCH METHODOLOGY}

This study examined both the cost of health care system (direct cost) and cost of non-medical (indirect cost) for children ( $<24$ months old) due to diarrhea and PRD that caused by not breastfeeding in North Sumatera.This study takes respondents from Serdang Bedagai Regency as the image of North Sumatera. We got this recommendation from Health Ministry of Indonesia, Jakarta. The research conducted interviews and secondary data collection from Sultan Sulaiman Syariful Alamsyah as regional public hospital, Melati Perbaungan Hospital as private hospital, and Tanjung Beringin Puskesmas as primary health center on 12-18 June 2016.

The research performed population attributable risk (PAR) percentage (Walters et al., 2016) to ensure that the diarrhea and PRD cases are happened because of inadequate breastfeeding. This research also calculate the diarrhea and PRD cases which happened in North Sumatra due to inadequate breastfeeding using census data (2010) and adjusted to Indonesia Demography Health Survey 2012(Siregar et al., 2018).

Children under two years using census data (2010) adjusted to 2012:

576.319

Estimated number of patients and cases of diarrhea and PRD due to inadequate breastfeeding in 2012

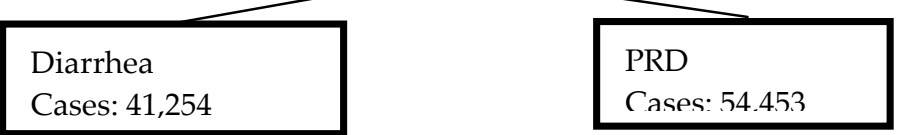

Source: Calculation based on Census Data 2010 and IDHS 2012 (siregar et al, 2018)

Figure 1.Total Prevalence of diarrhea and PRD in North Sumatera

This study got the total cost of not breastfeeding in the province of North Sumatra by multiplied the unit cost to total prevalence of diarrhea and PRD. This study calculates two kind of health cost. There are medical cost (health care system costs) and non-medical cost (patient cost). To calculate medical cost, we take information from health facility related to diarrhea and PRD for infants and children under two years old. Medical costs consist of supplies cost, health center worker fees, and service utilization. 
Whereas the non-medical costs consist of administration cost, treatment related cost, transportation cost, opportunity cost, and other accompanying families cost.

\section{RESULT AND DISCUSSION}

According to Table 1, the accompanying family member(s) for patients treated in all three facilities were mostly married females. The monthly expenditure of family members who visited the public hospital was US\$178, on average. They spent an average of 39 minutes to reach the hospital and 56 minutes in the hospital. Almost half of the family members used their own motorcycle to get to the hospital. Most of the patients surveyed in the public hospital suffered from both acute respiratory infections (PRD) and diarrhea.

Table 1.Characteristics of accompanying family member(s) $(\mathrm{n}=105$, cumulated from all facilities)

\begin{tabular}{|c|c|c|c|}
\hline \multirow[b]{2}{*}{ Items } & \multirow[b]{2}{*}{$\begin{array}{l}\text { Public } \\
\text { Hospital }\end{array}$} & \multicolumn{2}{|c|}{ Type of facility ${ }^{* *}$} \\
\hline & & $\begin{array}{l}\text { Private } \\
\text { Hospital }\end{array}$ & $\begin{array}{l}\text { Primary } \\
\text { Health Care } \\
\text { (Puskesmas) }\end{array}$ \\
\hline Age, mean (min-max) & $35(22-63)$ & $34(23-46)$ & $33(20-62)$ \\
\hline Female & $21(91 \%)$ & $26(93 \%)$ & $54(100 \%)$ \\
\hline Employed & $13(57 \%)$ & $9(32 \%)$ & $13(24 \%)$ \\
\hline Education (high school or higher) & $16(70 \%)$ & $12(43 \%)$ & $16(30 \%)$ \\
\hline Marital status (married) & $22(96 \%)$ & $25(89 \%)$ & $52(96 \%)$ \\
\hline $11(20 \%)$ & $3(1-5)$ & $3(1-7)$ & $3(1-6)$ \\
\hline \multicolumn{4}{|l|}{$43(80 \%)$} \\
\hline $13(3-60)$ & $11(48 \%)$ & $13(46 \%)$ & \\
\hline $27(10-100)$ & $12(52 \%)$ & $15(54 \%)$ & \\
\hline $131(22-300)$ & $39(10-120)$ & $35(5-120)$ & \\
\hline $\begin{array}{l}\text { Time spent in hospital in minutes, } \\
\text { mean (min-max) }\end{array}$ & $56(5-120)$ & $78(30-120)$ & \\
\hline Monthly expenditure, US\$$\$^{*}$, mean & $178(6-356)$ & $174(38-527)$ & \\
\hline \multicolumn{4}{|l|}{ Patient's type of disease } \\
\hline Diarrhea & $5(22 \%)$ & $17(61 \%)$ & $16(30 \%)$ \\
\hline PRD & $5(22 \%)$ & $9(32 \%)$ & $14(26 \%)$ \\
\hline Diarrhea and PRD & $13(56 \%)$ & $2(7 \%)$ & $24(44 \%)$ \\
\hline
\end{tabular}

**Exchange rate Rp13, 120/US\$ (2016) 
Of those visiting the private hospital, their monthly expenditure was US $\$ 174$, on average. They spent an average of 35 minutes to reach the hospital and 78 minutes in the hospital; this was a much higher time in the hospital than the other facilities surveyed. Similar to the public hospital, almost half of the patients in our survey used their own motorcycle to get to the hospital. There were a higher percentage of diarrhea cases in the private hospital than in the other facilities surveyed. At the primary health center (puskesmas), the monthly expenditure for accompanying family members was US\$131, on average, the lowest of the health facilities surveyed. They spent an average of 13 minutes to reach the hospital and approximately 27 minutes obtaining services.

It seems that the cases of either from diarrhea or both PRD and diarrhea are commonly found in the community-based facilities based on our survey. The time required reaching the facilities and the time spent in the facilities are similar for public hospital and private hospital. Interestingly, the time spent related to private hospital is almost 1.5 times higher than public hospital and 2-3 times higher than primary health care (puskesmas). Based on our observation, we think this may be because the private hospital is located in densely populated area, which means the hospital serves quite an amount of patients, therefore the waiting time is relatively longer.

Table 2 presents the costs of outpatient and inpatient services related to diarrhea and PRD in a public hospital. For outpatient services from the provider perspective, the unit cost per patient is dominated by supplies (medical drugs) costs. However, for inpatient services, the unit cost per patient is dominated by medical equipment and furniture/space following by supplies (medical drugs). The total costs per patient from a societal perspective for inpatient services are roughly 15 times higher than those for outpatient services.

Table 3 summarizes the treatment costs in a private hospital. The total cost (societal perspective) of outpatient in both hospitals in our survey has the highest cost compare to the total cost (societal perspective) of inpatient. According to Tables 2 and 3, a patient cost in inpatient service in the public hospital is 1.2 times greater than those same costs in the private hospital. Table 4 shows the medical equipment and furniture/space as the biggest influence on the medical costs from the provider perspective at the primary 
health center.

Table 2.Costs of outpatient and inpatient services for diarrhea and PRD, public hospital in Serdang Bedagai district ${ }^{* \wedge}$

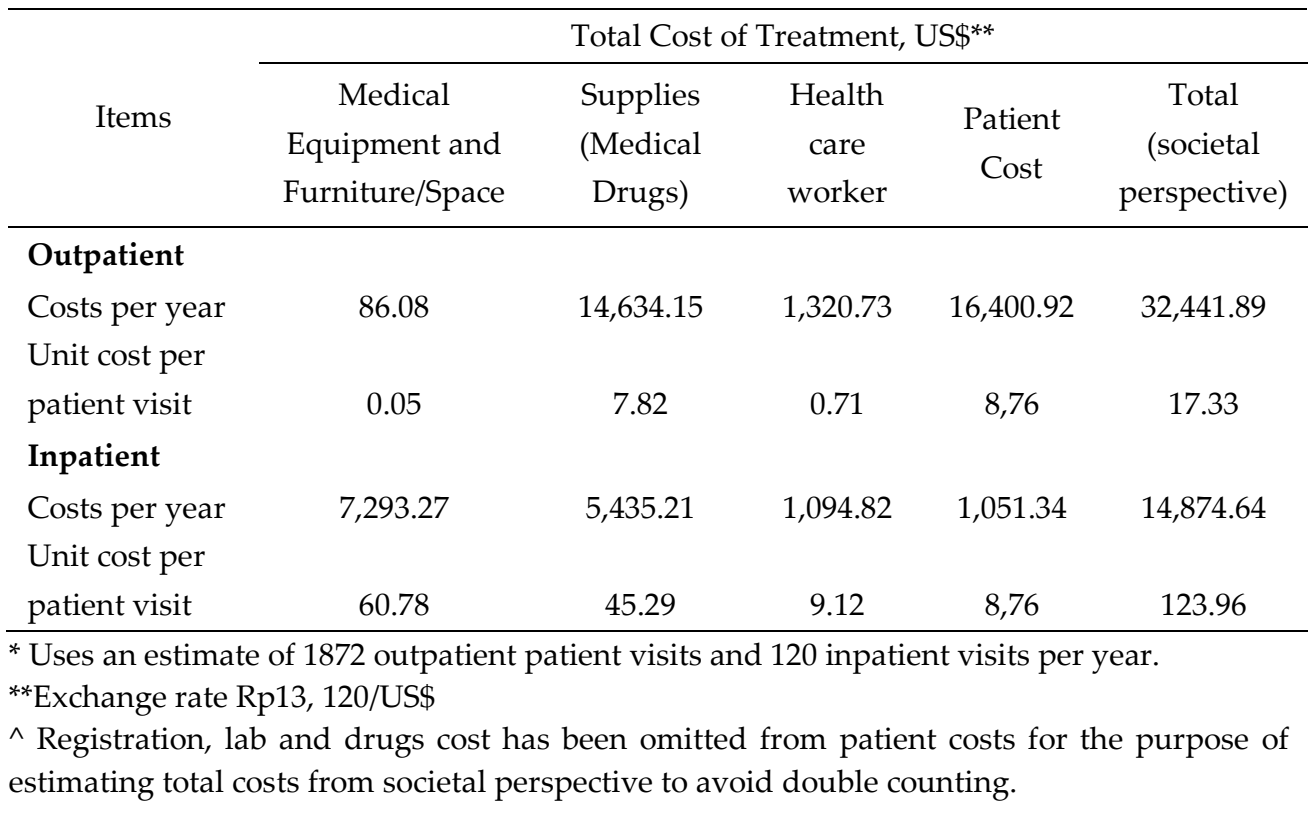

Table 3.Costs of outpatient and inpatient services for diarrhea and PRD, private hospital in Serdang Bedagai district ${ }^{* \wedge}$

\begin{tabular}{lccccc}
\hline & \multicolumn{5}{c}{ Total Cost of Treatment, USS\$ ${ }^{* *}$} \\
\cline { 2 - 6 } & $\begin{array}{c}\text { Medical } \\
\text { Equipment and } \\
\text { Furniture/Space }\end{array}$ & $\begin{array}{c}\text { Supplies } \\
\text { (Medical } \\
\text { Drugs) }\end{array}$ & $\begin{array}{c}\text { Health care } \\
\text { worker }\end{array}$ & $\begin{array}{c}\text { Patient } \\
\text { Cost }\end{array}$ & $\begin{array}{c}\text { Total } \\
\text { (societal } \\
\text { perspective) }\end{array}$ \\
\hline $\begin{array}{l}\text { Outpatient } \\
\text { Costs per year }\end{array}$ & 233.23 & $7,317.00$ & 826.37 & $4,794.31$ & $13,170.98$ \\
$\begin{array}{l}\text { Unit cost per } \\
\text { patient visit }\end{array}$ & 0.19 & 6.10 & 0.69 & 4.00 & 10.98 \\
$\begin{array}{l}\text { Inpatient } \\
\text { Costs per year }\end{array}$ & 431.50 & $6,219.51$ & 381.40 & 862.98 & $7,895.39$ \\
$\begin{array}{l}\text { Unit cost per } \\
\text { patient visit }\end{array}$ & 2.00 & 28.79 & 1.77 & 4.00 & 36.55 \\
\hline
\end{tabular}

* Estimated 1200 patient visits for outpatient and 216 patient visits for inpatient per year.

**Exchange rate Rp13, 120/US\$

$\wedge$ Registration, lab and drugs cost has been omitted from patient costs for the purpose of estimating total costs from societal perspective to avoid double counting. 
This trend is similar to the costs of outpatient treatment in the public hospital in which medical equipment and furniture/space are the primary cost driver from the provider perspective. The cost per patient visits is much lower for the primary health center than the hospitals.

Table 4.Costs of outpatient services for diarrhea and PRD, primary health center in Serdang Bedagai district ${ }^{* \wedge}$

\begin{tabular}{lccccc}
\hline & \multicolumn{5}{c}{ Total Cost of Treatment* } \\
\cline { 2 - 6 } \multicolumn{1}{c}{ Items } & $\begin{array}{c}\text { Medical } \\
\text { Equipment and } \\
\text { Furniture/Space }\end{array}$ & $\begin{array}{c}\text { Supplies } \\
\text { (Medical } \\
\text { Drugs) }\end{array}$ & $\begin{array}{c}\text { Health } \\
\text { care } \\
\text { worker }\end{array}$ & $\begin{array}{c}\text { Patient } \\
\text { Cost }\end{array}$ & $\begin{array}{c}\text { Total (societal } \\
\text { perspective) }\end{array}$ \\
\hline $\begin{array}{l}\text { Costs per } \\
\text { year }\end{array}$ & 73.20 & 51.07 & 187.46 & $4,931.93$ & $5,243.66$ \\
$\begin{array}{l}\text { Unit cost per } \\
\text { patient visit }\end{array}$ & 0.23 & 0.02 & 0.09 & 2.73 & 2.56 \\
\hline
\end{tabular}

* estimated 2052 patient visits for outpatient per year.

*Exchange rate Rp13, 120/US\$

$\wedge$ Registration, lab and drugs cost has been omitted from patient costs for the purpose of estimating total costs from societal perspective to avoid double counting.

Patient Costs

Based on patient costs per visit in Tables 5 to 7 , the highest average patient cost in all facilities, except for the cost of treatment related in primary health, and are incurred by patients suffering from PRD. The highest patient costs are found at the public hospital, second in primary health center and last in private hospital. Patient will lose income due to diarrhea and PRD disease about US\$ 7.56 per visit in public hospital, US\$ 5.35 per visit in primary health center, and US\$ 1.49 per visit in private hospital. These high costs are driven by large productivity losses. This is primarily because the accompanying family members work outside the home, though the longer transport time (and distance) and the time spent in the facility also contribute.

The patient costs in the private hospital was lower than patient cost in public hospital and primary health center because less people go to private hospital compare to public hospital and primary health center. That caused the patients spent less time in private hospital due to less queue time. Less time spent in private hospital create less opportunity cost loss. 
Table 5.Patient costs per visit, public hospital $(n=23)$

\begin{tabular}{lcccc}
\hline \multirow{2}{*}{ Disease } & \multicolumn{4}{c}{ Costs, US\$, mean per patient per visit (min-max)** } \\
\cline { 2 - 5 } & $\begin{array}{c}\text { Transport (all } \\
\text { members) }\end{array}$ & $\begin{array}{c}\text { Productivity Loss } \\
\text { (incl. family) }\end{array}$ & $\begin{array}{c}\text { Treatment } \\
\text { related }\end{array}$ & Total \\
\hline Diarrhea & $1.37(0.76-1.52)$ & $5.42(0-13.89)$ & $0.61(0-1.52)$ & $7.40(0-16.93)$ \\
PRD & $8.34(1.52-33.69)$ & $7.51(0-36.12)$ & $1.22(0-1.52)$ & $17.07(1.52-71.33)$ \\
$\begin{array}{l}\text { Diarrhea } \\
\text { and PRD }\end{array}$ & $1.37(0.76-1.83)$ & $5.72(0-37.05)$ & $0.47(0-1.52)$ & $7.56(0.76-40.4)$ \\
\hline${ }^{* *}$ Exchange rate Rp13, 120/US\$ & & &
\end{tabular}

Table 6.Patient costs per visit, private hospital $(n=28)$

\begin{tabular}{lcccc}
\hline \multirow{2}{*}{ Disease } & \multicolumn{4}{c}{ Costs, US\$, mean per patient per visit (min-max)** } \\
\cline { 2 - 5 } & $\begin{array}{c}\text { Transport (all } \\
\text { members) }\end{array}$ & $\begin{array}{c}\text { Productivity Loss } \\
\text { (incl. family) }\end{array}$ & $\begin{array}{c}\text { Treatment } \\
\text { related }\end{array}$ & Total \\
\hline Diarrhea & $1.93(0.38-7.62)$ & $1.61(0-8.89)$ & $0.22(0-3.81)$ & $3.76(0.38-20.32)$ \\
PRD & $2.63(1.52-7.62)$ & $2.98(0-7.54)$ & $5.42(0-26.68)$ & $11.03(1.52-41.84)$ \\
$\begin{array}{l}\text { Diarrhea and } \\
\text { PRD }\end{array}$ & $0.76(0.76-0.76)$ & $0.73(0-1.46)$ & $0(0-0)$ & $1.49(0.76-2.22)$ \\
\hline
\end{tabular}

**Exchange rate Rp13, 120/US\$

Table 7.Patient costs per visit, primary health center (puskesmas) $(n=54)$

\begin{tabular}{lcccc}
\hline \multirow{2}{*}{ Disease } & \multicolumn{4}{c}{ Costs, US\$, mean per patient per visit (min-max)** } \\
\cline { 2 - 5 } & $\begin{array}{c}\text { Transport (all } \\
\text { members) }\end{array}$ & $\begin{array}{c}\text { Productivity Loss } \\
\text { (incl. family) }\end{array}$ & $\begin{array}{c}\text { Treatment } \\
\text { related }\end{array}$ & Total \\
\hline Diarrhea & $0.76(0-4.57)$ & $0.08(0-0.77)$ & $0.39(0-0.91)$ & $1.23(0-6.25)$ \\
PRD & $3.12(0-16.77)$ & $0.39(0-1.69)$ & $0.33(0-2.06)$ & $3.84(0-20.52)$ \\
$\begin{array}{l}\text { Diarrhea and } \\
\text { PRD }\end{array}$ & $4.57(0-67.23)$ & $0.45(0-6.12)$ & $0.33(0-3.05)$ & $5.35(0-76.4)$ \\
\hline
\end{tabular}

**Exchange rate Rp13, 120/US\$

Table 8 shows the total loss due to inadequate breastfeed in North Sumatera. The table shows total yearly cost for both diarrhea and PRD are US $\$ 1,290,582$ with average cost about US $\$ 13.48$. The total cost consist of health system perspective cost about US\$ 799,050 and patient costs about 491,532. This show that most of the cost comes from the health system 
cost $/$ medical cost about $61.91 \%$ and the $38.09 \%$ borne from the patient costs and non- medical cost.

Table 8.Total Cost of Not Breastfeeding due to Diarrhea and PRDIn North Sumatera (US\$) **

\begin{tabular}{lrrrr}
\hline & $\begin{array}{c}\text { Health System } \\
\text { (Direct Cost) }\end{array}$ & $\begin{array}{c}\text { Patient Cost } \\
\text { (Indirect Cost) }\end{array}$ & Total Cost & $\begin{array}{r}\text { Unit Cost of } \\
\text { Total Cost }\end{array}$ \\
\hline Public Hospital & & & & \\
\hline Outpatient & $16,040.97$ & $16,400.92$ & $32,441.89$ & 17.33 \\
Inpatient & $13,823.30$ & $1,051.34$ & $14,874.64$ & 123.96 \\
Private Hospital & & & & 10.98 \\
\hline Outpatient & $8,376.67$ & $4,794.31$ & $13,170.98$ & 36.55 \\
Inpatient & $7,032.41$ & 862.98 & $7,895.39$ & 2.56 \\
Primary Health Center & & & & 13.48 \\
\hline Outpatient & 311.73 & $4,931.93$ & $5,243.66$ & \\
Total & $45,585.08$ & $28,041.48$ & $73,626.56$ & \\
\hline Total Diarrhea and PRD Cases & $\mathbf{9 5 , 7 0 7}$ & & \\
Total Cost of Diarrhea and PRD & $\mathbf{1 , 2 9 0 , 5 8 2}$ & & \\
Unit Cost of Health System & $\mathbf{7 9 9 , 0 5 0}$ & $\mathbf{6 1 . 9 1 \%}$ & \\
Unit Cost of Patient Cost & $\mathbf{4 9 1 , 5 3 2}$ & $\mathbf{3 8 . 0 9 \%}$ & \\
\hline \multirow{x}{**}{ Exchange rate Rp13, 120/US\$ } & & & \\
\hline
\end{tabular}

**Exchange rate Rp13, 120/US\$

\section{CONCLUSION AND SUGGESTION}

Conclusion

The costing process shows there are economic loss about US\$1,290,582 in North Sumatera. This is because the government and the public must pay the cost of diarrhea and PRD treatment caused by not breastfeeding. The other members of family also have to loss their productivity due to accompanying of their sick babies to the facilities. Compare to health budget of North Sumatera about US\$ 31,416,484 in 2012 (Directorate General of Fiscal Balance of Indonesia, 2016), the government should spend US\$ 799,050 on health system costs due to inadequate breastfeeding, indicating that the government has spent $3 \%$ of the health budget only to finance diarrhea and PRD due to inadequate breastfeeding. This is a huge loss for North Sumatera. 
Suggestion

The Government of North Sumatera should begin to seriously make policies to provide a campaign of the importance of breastfeeding to all society in North Sumatera. The government also must ensure that all health staffs have enough information about importance of breastfeeding, so they can provide sufficient information to the entire society.

\section{DAFTAR PUSTAKA}

Bartick, M. C., Stuebe, A. M., Schwarz, E. B., Luongo, C., Reinhold, A. G., \& Foster, E. M. (2013). Cost analysis of maternal disease associated with suboptimal breastfeeding. Obstetrics and Gynecology. https://doi.org/10.1097/AOG.0b013e318297a047

Binns, C., Lee, M., \& Low, W. Y. (2016). The Long-Term Public Health Benefits of Breastfeeding. Asia-Pacific Journal of Public Health. https://doi.org/10.1177/1010539515624964

Byford, S., Torgerson, D. J., \& Raftery, J. (2000). Economic Note: Cost of illness studies. BMJ. https://doi.org/10.1136/bmj.320.7245.1335

Clabaugh, G., \& Ward, M. M. (2008). Cost-of-illness studies in the United States: A systematic review of methodologies used for direct cost. Value in Health. https://doi.org/10.1111/j.1524-4733.2007.00210.x

Directorate General of Fiscal Balance of Indonesia. (2016). APBD, Realisasi $A P B D$, dan Neraca. Jakarta. Retrieved from http://www.djpk.depkeu.go.id/?page_id=316

Jo, C. (2014). Cost-of-illness studies: concepts, scopes, and methods. Clinical and Molecular https://doi.org/10.3350/cmh.2014.20.4.327

Hepatology.

Karim, F., Billah, S. M., Ahsanul, M., Chowdhury, K., Zaka, N., Manu, A., ... Khan, S. (2018). Initiation of breastfeeding within one hour of birth and its determinants among normal vaginal deliveries at primary and secondary health facilities in Bangladesh: A caseobservation study. PLoS ONE, 13(8), 1-15. https://doi.org/10.1371/journal.pone.0202508

Lamberti, L. M., Fischer Walker, C. L., Noiman, A., Victora, C., \& Black, R. E. (2011). Breastfeeding and the risk for diarrhea morbidity and QE Journal | Vol.07 - No.03December 2018 - 201 
mortality. BMC Public Health. https://doi.org/10.1186/1471-245811-S3-S15

Rice, D. P. (2000). Cost of illness studies: What is good about them? Injury Prevention. https://doi.org/10.1136/ip.6.3.177

Rich-Edwards, J. W., Stampfer, M. J., Manson, J. A. E., Rosner, B., Hu, F. B., Michels, K. B., \& Willett, W. C. (2004). Breastfeeding during infancy and the risk of cardiovascular disease in adulthood. Epidemiology. https://doi.org/10.1097/01.ede.0000129513.69321.ba

Riordan, J. M. (1997). The Cost of Not Breastfeeding: A Commentary. Journal of Human Lactation. https://doi.org/10.1177/089033449701300202

Siregar, A. Y. M., Pitriyan, P., \& Walters, D. (2018). The annual cost of not breastfeeding in Indonesia: The economic burden of treating diarrhea and respiratory disease among children $(<24 \mathrm{mo})$ due to not breastfeeding according to recommendation. International Breastfeeding Journal, 13(1), 1-10. https://doi.org/10.1186/s13006018-0152-2

Statistics of North Sumatera. (2016). North Sumatera Province In Figures 2016.

Tarricone, R. (2006). Cost-of-illness analysis. What room in health economics? Health Policy. https://doi.org/10.1016/j.healthpol.2005.07.016

United Nations Children's Fund. (2012). Infant and Young Child Feeding Programming Status. Nutrition Section, UNICEF. https://doi.org/http://www.unicef.org/nutrition/files/Final_IYCF_ programming_guide_2011.pdf

Victora, C. G., Bahl, R., Barros, A. J. D., França, G. V. A., Horton, S., Krasevec, J., ... Richter, L. (2016). Breastfeeding in the 21st century: Epidemiology, mechanisms, and lifelong effect. The Lancet. https://doi.org/10.1016/S0140-6736(15)01024-7

Walters, D., Horton, S., Siregar, A. Y. M., Pitriyan, P., Hajeebhoy, N., Mathisen, R., ... Rudert, C. (2016). The cost of not breastfeeding in Southeast Asia. Health Policy and Planning. https://doi.org/10.1093/heapol/czw044 